\title{
PELATIHAN MANAJEMEN TAMAN PENDIDIKAN AL-QUR'AN NURUL HIDAYAH GETAP BARAT KELURAHAN CAKRANEGARA SELATAN KEC. CAKRANEGARA KOTA MATARAM
}

\author{
Subki \\ Dosen Prodi. Pendidikan Matematika, UIN Mataram
}

\begin{abstract}
Abstrak: Seiring dengan kemajuan ilmu pengetahuan dan teknologi yang semakin canggih yang berdampak pada semakin menjamurnya lembaga pendidikan, baik swasta maupun negeri, baik lembaga pendidikan formal maupun non formal, mulai dari perkotaan sampai [edesaan dan bahkan pelosok sekalipun, menuntut kepada semua penentu kebijakan baik pemerintah dan terlebih lagi bagi para pemangku kepentingan atau penentu kebijakan strategis pada masing-masing lembaga pendidikan yang bersangkutan untuk terus berbenah diri.

Taman Pendidikan al-Qur'an (TPQ) Nurul Hidayah Getap Barat hadir di tengahtengah masyarakat Getap Barat yang berada di wilayah kecamatan Cakranegara sebagai pusat perekonomian warga Mataram khususnya dan provinsi Nusa Tenggara Barat umumnya, sebagai wadah untuk membekali generasi muda dalam menghadapi perkembangan zaman dan teknologi serta informasi yang disajikan melalui media masa baik cetak maupun eketronik. Keberadaan sebuah lembaga pendidikan di tengah menjamurnya lembaga pendidikan di berbagai penjuru mulai dari perkotaan sampai pedesaan dan bahkan pelosok kampung terpencil sekalipun, akan dapat eksis manakala lembaga pendidikan yang bersangkutan dikelola dan ditata dengan baik.

Untuk mencapai tujuan tersebut, maka kegiatan pengabdian ini difokuskan pada pelatihan manajerial Taman Pendidikan al-Qur'an Nurul Hidayah getap Barat, dengan mengundang narasumber yang mumpuni di bidang manajemen. Kegiatan pengabdian tersebut dilaksanakan dengan menerampakan metode ceramah, tanya jawab dan pemberian tugas atau latihan. Kegiatan tersebut dihadiri oleh 15 orang peserta, dengan rincian seorang kepala, tiga orang wakil (kesiswaan, kurikulum, dan sarana prasarana), seorang Bendahara dan 10 orang guru. Materi yang disampaikan pada saat pelatihan berkisar pada fungsi manajemen, yaitu perencanaan, pengorganisasian, pelaksanaan dan pengawasan. Masing-masing fungsi tersebut diperkuat oleh narasumber dengan memberikan ruang tanyajawab dan latihan sederhana kepada peserta.
\end{abstract}

Kata Kunci: fungsi manajemen, lembaga pendidikan, maju dan terkemuka.

\section{PENDAHULUAN}

Taman Pendidikan al-Qur'an (TPQ) Nurul Hidayah adalah satu-satunya Taman Pendidikan al-Qur'an yang ada di lingkungan Getap Barat kelurahan Cakra Selatan Baru Kecamatan Cakranegara Kota Mataram. Secara geografis, Lingkungan Getap Barat merupakan lingkungan yang berdampingan dengan lingkungan Panaraga Sebelah Barat, lingkungan Karang Kecicang sebelah Utara, lingkungan Karang Kajanan sebelah Selatan dan lingkungan Getap Timur sebelah Timur. Tiga lingkungan di atas (Panaraga, Karang Kecicang dan Karang Kajanan) merupakan lingkungan yang masyarakatnya penganut agama Hindu/Bali, 
sedangkan lingkungan Getap (Timur, Barat dan Getap Timuk Oloh/GTO), masyarakatnya penganut agama Islam.

Mengacu pada letak geografis tersebut, tidak menutup kemungkinan anakanak lingkungan Getap Barat bergaul dan bermain dengan anak-anak di tiga lingkungan tersebut yang nota benenya beragama Hindu. Dari pergaulan itulah, mereka melihat dan secara tidak sengaja terkadang meniru adat kebiasaan yang berlaku di keluarga Hindu dan sebaliknya.

Kondisi seperti itu membutuhkan perhatian serius bagi masyarakat setempat untuk memikirkan cara membentengi anak-anak mereka terutama dengan pendidikan agama. Karena itulah, masyarakat Getap Barat sepakat mendirikan Taman Pendidikan al-Qur'an yang dengan nama "TPQ Nurul Hidayah Getap Barat". Pemberian nama tersebut disesuaikan dengan nama masjid yang menanungi TPQ itu sendiri, yaitu masjid Nurul Hidayah Getap Barat. Keberadaan TPQ Nurul Hidaya Getap Barat disambut positif oleh masyarakat setempat. Hal ini terbukti dengan banyaknya masyarakat yang hadir pada saat peresmian TPQ Nurul Hidayah oleh Wali Kota Mataram (alm. Bpk. H. Muh. Ruslan, SH), dan diikuti oleh banyaknya santri yang belajar mengaji di TPQ tersebut. Namun sangat disayangkan, antusias santri yang belajar di TPQ tersebut tidak bertahan lama. Hal ini disebabkan karena tidak adanya sistim pengelolaan yang jelas oleh pengurus kala itu. Salah satu indikator tidak adanya pengelolaan yang jelas adalah terkait dengan administrasi dan perekrutan tenaga pengajar yang tidak ada kejelasan. Siapa yang mau, dialah yang naik ke lantai dua untuk mengajar anak-anak. Keadaan seperti ini berlangsung sampai pada akhir tahun 2014.

Karena itu pada waktu itu keberadaan TPQ Nurul Hidayah Getap Barat bisa dikatakan hidup enggan mati tak mau, artinya santri yang belajar di tempat tersebut semakin hari semakin berkurang dan tidak terurus dengan baik. Terkadang beberapa orang santri turun dari lantai dua (yang merupakan pusat kegiatan belajar mengajar) ke lantai satu hanya sekedar mencari guru (jamaah sholat) yang akan membimbingnya dalam membaca al-Qur'an. Keadaan seperti ini sering pengabdi jumpai ketika pengabdi ikut sholat berjamaah di masjid tersebut. Sementara santri yang lain bertahan di lantai dua dengan kegiatan saling menyimak antara santri senior dengan yunior. 
Kehadiran Muhammad Aeko Zulham, S. Pd membawa perubahan dan kemajuan yang cukup signifikan. Sebagai indikator kemajuan TPQ tersebut adalah semakin bertambahnya jumlah santri yang belajar di tempat tersebut. Hanya saja sangat di sayangkan, akhir-akhir ini Muhammad Aeko tidak lagi aktif lantaran yang bersangkutan seibuk mengurusi lembaga pendidikan PAUD yang baru didirikannya. Akhirnya saat ini, selaku penanggungjawab TPQ di serahkan kepada Juni Indrajib yang sebelumnya hanya bertugas sebagai tenaga pengajar biasa. Menurut informasi dari Juni Hendrajid ${ }^{7}$ saat ini jumlah santri yang belajar di TPQ Nurul Hidayah adalah 218 orang santri dengan jumlah tenaga pengajar sebanyak 15 orang. Ke lima belas orang tenaga pengajar tersebut berlatar belakang dari pendidikan dan status yang berbeda. Ada yang sudah selesai kuliah, ada yang sedang kuliah, ada yang sudah berkeluarga, dan bahkan ada yang hanya mengenyam pendidikan sampai madrasah aliyah namun yang bersangkutan bersedia membantu mengajar mengabdikan diri bersama guru yang lainnya.

Walaupun TPQ Nurul Hidayah mengalami kemajuan yang signifikan terutama dilihat dari segi kuantitas santri, namun sangat disayangkan bahwa TPQ Nurul Hidayah belum dikelola secara baik. Menurut penuturan Hendra, bahwa yang menjadi permasalahan yang dipandang sangat krusial saat ini adalah terkait dengan pengelolaan TPQ Nurul Hidayah yang sampai saat ini masih berjalan seperti yang dipraktikkan oleh orang tua jaman dulu. Artinya, TPQ Nurul Hidayah tidak dikelola secara profesional. Santri tidak pernah diabsen dan pembagian kelompokpun dilakukan berdasarkan tingkat pengajian ( iqro', alif bata dan qur'an besar). Sementara terkait dengan honor atau gaji bagi para pengajar tidak menentu, karena di TPQ tersebut tidak memungut biaya kepada para santri. Kalau ada warga yang bersedekah, baru guru mendapatkan rezki, kalau tidak, ini agak susah dan tidak bisa memaksakan rekan guru untuk terus aktif mengajar, terutama yang sudah berkeluarga. Kalau kondisi seperti ini dibiarkan berlarutlarut, maka tidak menutup kemungkinan nasib TPQ Nurul Hidayah akan kembali seperti semula yang kehilangan santrinya lantaran TPQ tersebut tidak dikelola secara profesional.

\footnotetext{
${ }^{7}$ Kepala TPQ Nurul Hidayah Getap Barat, wawancara 2 April 2017 di masjid Nurul Hidayah Getap Barat.
} 
Walaupun demikian, pengabdi memiliki harapan yang besar bahwa TPQ Nurul Hidayah Getap Barat akan bisa berkembang, terutama dari segi kuantitas. Hal ini terbukti semakin banyaknya santri baru yang datang belajar pada TPQ tersebut. Menurut hemat pengabdi, bahwa salah satu daya tarik yang membuat masyarakat memasukkan putra-putrinya pada TPQ tersebut adalah karena TPQ tersebut memiliki grup Shalawat yang biasa ditampilkan pada saat warga masyarakat mengundang mereka untuk acara hajatan keluarga. Di samping itu, pengurus masjid juga sudah memprogramkan dan termasuk menjadi rutinitas acara khataman al-Qur'an oleh para santri TPQ Nurul Hidayah yang telah menamatkan pengajian qur'an besar pada saat perayaan maulid Nabi Muhammad saw.

Berangkat dari kondisi sebagaimana dipaparkan di atas, pengabdi merasa terpanggil untuk melakukan pendampingan dalam pengelolaan Taman Pendidikan al-Qur'an, sehingga dengan demikian, diharapkan TPQ tersebut dapat berjalan dengan lancar dan mampu mengikuti perkembangan zaman terutama dalam hal pengelolaan pembelajaran dan kurikulum pendidikan. Sebagai upaya mendukung terwujudnya cita-cita tersebut, maka dalam kegiatan ini pengabdi melibatkan berbagai pihak terutama yang memiliki kemampuan dalam manajerial/ pengelolaan, termasuk juga mengundang pengelola TPQ yang lain yang dianggap sudah maju di kecamatan Cakranegara dan sekitarnya, seperti TPQ yang ada di Kelurahan Babakan Kecamatan Sandubaya Kota Mataram.

\section{PEMBAHASAN}

\section{A. Strategi Pengabdian}

Dalam rangka menunjang ketercapaian tujuan yang diharapkan, dalam kegiatan ini pengabdi menempuh beberapa strategi atau metode, antara lain ceramah, tanya jawab, dan latihan/penugasan. Metode ceramah diterapkan untuk memberikan informasi kepada peserta tentang pentingnya manajemen atau pengelolaan dalam sebuah lembaga pendidikan, dan beberapa informasi lainnya terkait dengan pengelolaan lembaga pendidikan. Metode tanya jawab dipergunakan untuk memberikan kesempatan bagi peserta dalam mendalami 
informasi atau materi yang diberikan melalui metode ceramah tersebut. Sedangkan metode latihan atau penugasan dipergunakan untuk memberikan kesempatan dan sekaligus memperkuat pengetahuan dan kemampuan peserta dalam mengelola lembaga pendidikan.

Agar kegiatan pendampingan ini dapat berjalan dengan baik dan mencapai hasil maksimal, maka dalam pelaksanaan kegiatan tersebut pengabdi menjalin kerjasama dengan berbagi pihak yang memiliki pengetahuan dan pengalaman di bidang manajemen atau pengelolaan lembaga pendidikan Islam. Terkait dengan ilmu manajemen dan pengelolaan, pengabdi meminta kesedian bebera orang narasumber yang memiliki latar belakang manajemen pendidikan seperti narasumber yang memiliki kemampuan di bidang manajerial. Sedangkan terkait dengan pengelaman pengelolaan, pengabdi menghubungi narasumber yang dinilai telah berhasil mengelola lembaga pendidikan (TPQ) seperti pengelola TPQ di Kelurahan Babakan kecamatan Sandubaya. Sedangkan yang menjadi sasaran atau target dalam pelaksanaan kegiatan ini adalah para guru dan pengurus TPQ Nurul Hidayah Getap Barat.

Untuk mendukung kelancaran pelaksanaan kegiatan dimaksud, keberadaan dan kemampuan sumber daya manusia terutama pengabdi sangat menentukan. Karena itu, pengabdi sengaja memilih jenis kegiatan berupa pengelolaan TPQ Nurul Hidayah sebagai kegiatan dalam pengabdian ini karena pengabdi sendiri mengambil jurusan Manajemen Pendidikan Islam pada program doktor di Universitas Islam Negeri Malang. Demikian pula halnya dengan kekuatan internal yang dimiliki TPQ Nurul Hidayah Getap Barat yang saat ini diasuh oleh 15 orang tenaga pengajar dengan berbagai jenjang dan jurusan pendidikan, mulai dari sarjana, mahasiswa dan pelajar tingkat SMA sederajat. Sedangkan dari sisi sumber daya alam yang tersedia, kegiatan ini diyakini dapat berjalan dengan lancar karena adanya daya dukung dari masyarakat setempat terutama dalam hal menjaga kondusifitas kegiatan dan keberpihakan warga masyarakat dalam mengundang santri untuk acara hajatan. 
B. Pelaksanaan Kegiatan Pengabdian

Kegiatan pengabdian yang berlangsung di Taman Pendidikan al-Qur'an Nurul Hidayah Getap terbagi menjadi dua tahapan. Tahap pertama berlangsung pada hari Sabtu tanggal 9 September 2017 dan tahap kedua pada hari Sabtu tanggal 16 September 2017. Sedangkan kegiatan yang berlangsung pada tahap kedua Sabtu tanggal 16 September 2017 hanya bersifat monitoring dan diskusi antara pengabdi dengan tenaga pendidik yang ada di Taman Pendidikan al-Qur'an Nurul Hidayah Getap Barat Kelurahan Cakranegara Selatan Kecamatan Cakranegara Kota Mataram.

Pelaksanaan kegiatan pada tahap pertama yang berlangsung pada hari Sabtu tanggal 9 September 2017 dibagi menjadi tiga kegiatan, yaitu pendahuluan, kegiatan inti dan kegiatan penutup.

1. Kegiatan Pendahuluan.

Sembari menyambut kehadiran peserta memasuki ruangan tempat berlangsungnya acara pelatihan, petugas pendamping duduk di depan pintu sambil membagikan ATK kepada peserta yang memasuki ruangan. Setelah 30 menit menunggu, semua peserta sudah berada di ruang tempat acara pelatihan, dan acarapun segera dimulai.

Pelaksanaan kegiatan diawali dengan acara pembukaan dengan rangkaian acara: pembukaan oleh Husnul Khotimah selaku MC, sambutan kepala Guru /Ustadz (Ust. M. Juni Hendraji). Dalam sambutannya, Hendrajid menyampaikan ucapan terima kasih kepada pengabdi beserta tim yang telah berkenan memberikan informasi dan pembekalan kepada guru-guru yang ada di Taman Pendidikan al-Qur'an Nurul Hidayah Getap Barat Kelurahan Cakranegara Selatan Kecamatan Cakranegara Kota Mataram dan sekaligus berharap semoga informasi yang akan diberikan dapat dijadikan bekal dan motivasi bagi tenaga pendidik atau para asatiz yang ada di Taman Pendidikan al-Qur'an Nurul Hidayah Getap Barat Kelurahan Cakranegara Selatan Kecamatan Cakranegara Kota Mataram dalam rangka membina dan mendidik peserta didik yang ada di Taman Pendidikan al-Qur'an Nurul Hidayah Getap Barat Kelurahan Cakranegara 
Selatan Kecamatan Cakranegara Kota Mataram. Demikian pula ucapan terima kasih disampaikan kepada semua peserta yang telah bersedia menghadiri acara ini.

Acara dilanjutkan dengan sambutan pengabdi. Pada kesempatan tersebut pengabdi menceritakan kronologis kegiatan, yaitu pengabdi terlebih dahulu melakukan identifikasi terhadap berbagai permasalahan yang dihadapi pihak Taman Pendidikan al-Qur'an Nurul Hidayah Getap Barat Kelurahan Cakranegara Selatan Kecamatan Cakranegara Kota Mataram. Setelah permasalahan teridentifikasi, langkah berikutnya yang pengabdi lakukan adalah menjalin hubungan dengan beberapa narasumber guna mekonfirmasi kesiapan masing-masing narasumber dalam mengisi acara terkait. Untuk lebih jelasnya beberapa kegiatan yang dilakukan pada tahap pendahuluan ini, dapat dipaparkan sebagai berikut:

Mengidentifikasi permasalahan yang muncul di Taman Pendidikan al-Qur'an Nurul Hidayah Getap Barat Kelurahan Cakranegara Selatan Kecamatan Cakranegara Kota Mataram. Dari sekian banyak permasalahan yang disampaikan oleh kepala asatidz/ah, selanjutnya pengabdi bertanya kepada yang bersangkutan kira-kira permasalahan yang mana yang dianggap paling mendesak dan urgen untuk dilaksanakan. Berdasarkan beberapa pertimbangan dan kondisi yang ada, akhirnya Kepala asatidz Taman Pendidikan al-Qur'an Nurul Hidayah Getap Barat Kelurahan Cakranegara Selatan Kecamatan Cakranegara Kota Mataram menyampaikan bahwa permasalahan yang paling urgen dan mendesak untuk dilaksanakan adalah terkait dengan manajemen sumber daya manusia, manajemen kesiswaan, manajemen administrasi, dan manajemen hubungan kemasyarakatan. Karena itu, pengabdi bersama kepala asatiz membangun kesepakatan untuk melaksanakan kegiatan pengabdian berupa manajemen penglolaan Taman Pendidikan al-Qur'an Nurul Hidayah Getap Barat Kelurahan Cakranegara Selatan Kecamatan Cakranegara Kota Mataram tahun anggaran 2017. 
Setelah disepakati jenis kegiatan yang dilakukan, selanjutnya pengabdi berkoordinasi dengan beberapa narasumber dan tenaga pendamping lainnya untuk membicarakan teknik dan materi pengabdian. Kepada narasumber, pengabdi menyampaikan bahwa kegiatan pengabdian kali ini disepakati dalam bentuk pelatihan manajerial lembaga pendidikan (Taman Pendidikan al-Qur'an Nurul Hidayah Getap Barat Kelurahan Cakranegara Selatan Kecamatan Cakranegara Kota Mataram). Hal ini dimaksudkan untuk memberikan kesempatan kepada narasumber untuk mempersiapkan diri terkait dengan materi yang akan disampaikan pada saat pelatihan dan sekaligus menentukan metode yang akan digunakan selama proses pelatihan berlangsung. Demikian pula halnya dengan tenaga pendamping lainnya, pengabdi juga menghubungi tiga orang yang akan mendampingi pengabdi dalam kegiatan tersebut, ketiga orang pendaming dimaksud masing-masing Abdus Somad, Muhammad Nasir dan Abdul Aziz.

Setelah pengabdi menghubungi narasumber dan pendamping pengabdian, selanjutnya pengabdi berkoordinasi dengan Kepala asatidz untuk mengambil kata sepakat atau membuat kesepakatan dengan kepala asatidz mengenai waktu pelaksanaan pengabdian dan sekaligus meminta kepala asatidz untuk mendata tenaga pendidik yang akan mengikuti kegiatan dimaksud.

Setelah berkoordinasi dengan kepala asatidz dan mendapatkan data guru yang akan mengikuti kegiatan pelatihan manajerial lembaga pendidikan (Taman Pendidikan al-Qur'an Nurul Hidayah Getap Barat Kelurahan Cakranegara Selatan Kecamatan Cakranegara Kota Mataram). Melaksakan kegiatan pelatihan penguatan manajerial madrasah di pelatihan manajerial lembaga pendidikan (Taman Pendidikan al-Qur'an Nurul Hidayah Getap Barat Kelurahan Cakranegara Selatan Kecamatan Cakranegara Kota Mataram) sebagai upaya untuk membenahi sistem manajemen yang berlangsung di pelatihan manajerial lembaga pendidikan (Taman Pendidikan al-Qur'an Nurul Hidayah Getap Barat Kelurahan 
Cakranegara Selatan Kecamatan Cakranegara Kota Mataram). Narasumber yang didatangkan atau dipakai dalam kegiatan tersebut adalah narasumber yang memiliki pengalaman dan pengetahuan di bidang manajemen. Narasumber tersebut diyakini memikili pengetahuan dan pengalaman di bidang manajemen karena yang bersangkutan telah kuliah pada jurusan Manajemen di jenjang S2 pada Universitas Negeri Malang. Melalui pelatihan dan praktik yang diikutinya saat mengikuti pelatihan ditambah dengan pengalamannya menjadi tim tutorial pada beberapa lembaga, baik formal maupun non formal menjadi alasan pengabdi untuk memintanya menjadi narasumber pada kegiatan ini.

2. Kegiatan Inti.

Pada tahap pertama kegiatan difokuskan pada penyampaian materi pokok terkait dengan manajemen pengelolaan lembaga pendidikan termasuk di dalamnya Taman Pendidikan al-Qur'an secara umum. Pada kesempatan tersebut nara sumber menyampaikan materi tentang manajemen, yang meliputi: manajemen kurikulum, manajemen personalia, manajemen kesiswaan, manajemen adiminstrasi sekolah, dan manajemen sarana dan prasarana.

a. Manajemen Kurikulum

Sebelum menyampaikan bagaimana tatakelola kurikulum dalam sebuah lembaga pendidikan, narasumber terlebih dahulu memberikan pemahaman kepada peserta pelatihan tentang makna kurikulum itu sendiri. Kurikulum dalam pengertian konvensional sering dimaknai sebagai seperangkat mata pelajaran yang harus ditempuh atau diterima peserta didik untuk memperoleh ijazah. Pandangan demikian berimplikasi pada kegiatan pembelajaran berorientasi kepada penuntasan materi, sehingga kompetensi lulusan yang dihasilkan hanya berbekal kecakapan kognitif belaka. Selain itu, implikasi tersebut berdampak pada kegiatan belajar mengajar sering berpusat kepada guru sehingga keterlibatan aktif peserta didik menjadi terbengkalai. 
Sedangkan kurikulum yang sesuai dengan kondisi kita di Taman Pendidikan, termasuk di dalamnya Taman Pendidikan al-Qur'an Nurul Hidayah Getap Barat, kurikulum hendaknya dimaknai sebagai segala pengalaman pendidikan yang diberikan oleh lembaga pendidikan yang bersangkutan kepada peserta didiknya baik yang dilakukan di dalam lembaga pendidikan tersebut maupun di luarnya.

Saat narasumber menyampaikan materi tentang konsep kurikulum sebagaimana dipaparkan di atas, salah seorang peserta bertanya, lantas dalam kaitannya dengan lembaga pendidikan yang kami bina ini, apa yang Bapak maksud dengan kurikulum?. Sejalan dengan yang saya sampaikan tadi, bahwa yang dimaksud dengan kurikulum di sini adalah segala sesuatu yang Bapak/Ibu berikan kepada peserta didik baik yang berlangsung di dalam proses pembelajaran maupun di luar proses pembelajaran yang berkontribusi bagi perkembangan peserta didik ke arah yang lebih baik. Karena itu, kepada Bapak/Ibu asatidz/asatizdah diharapkan mampu merancang dan mengelola segala aktivitas yang berlngsung dalam lembaga pendidikan yang ada di sini, dengan harapan nantinya ketika santri sudah menyelesaikan pembelajarannya di Taman Pendidikan Nurul Hidayah Getap Barat ini, mereka memiliki kemampuan baik di dalam membaca maupun menulis al-Qur'an serta memiliki keterampilan dalam melaksanakan solat dengan baik dan benar.

Peserta yang lainnya menimpali penjelasan narasumber dengan pertanyaan lanjutan, kalau begitu, bagaimana kami merancang kurikulum yang benar? Merancang sebuah kurikulum tentunya mengacu kepada manajemen kurikulum dengan menerapkan fungsi-fungsi manajemen yang ada, mulai dari perencanaan, pengorganisasian, pelaksanaan, sampai pada tahap pengevaluasian.

Kegiatan dalam perencanaan kurikulum dapat mengadopsi pendekatan yang digunakan dalam perencanaan pendidikan, karena 
kurikulum merupakan salah satu komponen pendidikan.Ada tiga pendekatan perencanaan pendidikan.

Pertama, pendekatan kebutuhan sosial, yaitu pendekatan yang didasarkan atas keperluan masyarakat pada saat ini. Pendekataan ini menitikberatkan pada tujuan pendidikan yang mengandung misi pemerataan kesempatan dalam mendapatkan pendidikan. Seperti misalnya wajib belajar (wajar) 9 tahun.

Kedua, pendekatan ketenagaan,yaitu pendekatan yang mengutamakan keterkaitan kelulusan sistem pendidikan dengan tuntutan akan kebutuhan tenaga kerja. Jika dikaji dari semakin membengkaknya angka pengangguran, maka keperluan mempertemukan kepentingan dunia pendidikan dengan kerja semakin mendesak. Contoh pendekatan ini adalah diterapkannya pendidikan sistem ganda (PSG) melalui kebijakan link and match.

Ketiga, pendekatan yang menitikberatkan pemanfaatan biaya secermat mungkin untuk dapat menghasilkan pendidikan yang seoptimal mungkin, baik secara kuantitatif maupun kualitatif. Pendekatan ini diadakan jika benar-benar memberikan keuntungan yang relatif pasti, baik bagi penyelenggara maupun peserta didik.

Dari sudut pandang organisasi, perencanaan kurikulum berperan menentukan tujuan dan maksud kurikulum, perkiraan-perkiraan lingkungan, dan penetapan pendekatan di mana maksud dan tujuan pengembangan kurikulum hendak dicapai. Dengan demikian pimpinan sekolah (kepala dan waka sekolah) memiliki kesempatan untuk berinisiatif menciptakan situasi yang menguntungkan sekolah. Tanpa perencanaan seseorang pemimpin hanya sekedar mereaksi masalah yang muncul dalam sekolah, yang mengakibatkan kurang memiliki sikap antisipatif. Oleh karena itu, pemimpin sekolah perlu menyusun perencanaan pengembangan kurikulum secara cermat, teliti, menyeluruh dan rinci serta melibatkan komponen termasuk guru.

Berdasarkan pada pemikiran di atas, maka yang dimaksud dengan perencanaan kurikulum adalah keputusan yang diambil untuk 
melakukan tindakan-tindakan selama waktu tertentu agar pelaksanaan kegiatan kurikulum menjadi efektif dan efisien serta menghasilkan kurikulum yang lebih baik dan relevan dengan kebutuhan stakeholder, kebutuhan pembangunan, dan perkembangan iptek.

Perencanaan kurikulum dimaksudkan di sini adalah bagaimana Bapak/Ibu merancang sebuah kurikulum yang laku di pasaran. Hal ini penting menjadi pertimbangan karena menjamurnya lembaga pendidikan seperti ini yaitu Taman Pendidikan al-Qur'an di berbagai kampung /lingkungan. Lembaga pendidikan hendaknya merancang sebuah kurikulum yang memiliki nilai plus yang menjadi daya tarik atau mitivasi bagi warga masyarakat sekitar untuk memasukkan putra putri mereka ke lembaga pendidikan yang dikelola. Namun demikian, penentuan jenis kegiatan atau program yang menjadi nilai plus lembaga pendidikan yang bersangkutan tentunya disesuaikan dengan sumber daya manusia atau SDM yang dimiliki. Hal ini dimaksudkan agar program yang telah direncanakan tersebut dapat berjalan dengan lancar dan mencapai hasil maksimal.

Penjelasan narasumber tersebut, disambut baik oleh peserta pelatihan, di antara mereka ada yang berkomentar, alhamdulillah, di samping menyelenggarakan kegiatan rutin berupa pembacaan al-Qur'an setiap malamnya, mulai dari sholat maghrib berjamaah sampai azan sholat isya', lembaga pendidikan Nurul Hidayah Getap Barat telah memiliki program tambahan yang mungkin belum dimiliki atau dilaksanakan oleh TPQ yang lainnya. Diantara program /kegiatan yang diadakan di lembaga pendidikan Taman Pendidikan al-Qur'an Nurul Hidayah Getap Barat adalah:

1) Marawis (menyelenggarakan kegiatan sholawat dibarengi dengan rebana/alat musik yang diikuti oleh santri/santriwati yang berumur 7 tahun ke atas). Dan alhamdulillah kegiatan hadlarah ini menjadi daya tarek tersendiri bagi warga masyarakat sekitar untuk memasukkan putra-putrinya di Taman Pendidikan al-Qur'an Nurul Hidayah Getap 
Barat. Di samping memasukkan putra-putrinya di lembaga pendidikan Taman Pendidikan al-Qur'an Nurul Hidayah Getap Barat, kelompok hadlarah juga sering diundang oleh warga masyarakat yang melaksanakan hajatan/acara tertentu.

2) Kegiatan lainnya yang diadakan di lembaga pendidikan Taman Pendidikan al-Qur'an Nurul Hidayah Getap Barat adalah mengadakan muhadlarah ( mengadakan latihan pidato yang diselenggarakan setiap malam jum'at). Kegiatan ini dimaksudkan sebagai sarana untuk melatih dan mengembangkan minat serta bakat masing-masing santri. Dalam kegiatan tersebut, secara bergiliran mereka bertugas sebagai Master of Ceremonia (MC), qari'/qariah dan khithobah/penceramah, serta pembacaan doa. Masing-masing posisi tersebut diisi oleh santri sesuai dengan kecenderungan dan bakatnya. Untuk mengisi posisi tersebut, para pembina tidak pernah memaksa santrinya untuk mengisi masing-masing posisi, melainkan memberikan kebebasan kepadea para santri yang bersangkutan untuk menentukan posisi apa yang ia inginkan. Hal ini dimaksudkan untuk memberikan kebebasan bagi santri untuk memilih dan sekaligus mengembangkan bakat dan minatnya masing-masing. Para pembina atau asatidz hanya bertugas membina dan mengarahkan serta membimbing santrinya sesuai dengan pilihannya masing-masing.

3) Kegiatan Mabit (malam pembinaan iman dan takwa). Kegiatan ini diselenggarakan dalam kurun waktu satu kali dalam tiga bulan. Kegiatan ini diikuti oleh santri/santriwati yang telah memasuki usia remaja. Hal ini dimaksudkan untuk membina dan membekali mereka dengan berbagai ilmu keagamaan yang nantinya diharapkan dapat membekas dalam kehidupan mereka sehari-hari. kegiatan ini sudah pernah diadakan di makam Cemare tebal yaitu sebuah makam yang dianggap keramat dan biasa dikunjungi oleh warga masyarakat Getap setiap akhir bulan maulid setelah mereka mencukur rambut bayinya. Dalam kegiatan mabit tersebut, pserta mabit di dampingi oleh wali/orangtua masing-masing. Peserta menginap selama satu malam, 
berangkat pada sore hari Sabtu dan pulang keesokan harinya yaitu pada hari Ahad pagi. Kegiatan tersebut diisi dengan beberapa acara, diawali dengan sholat magrib seracara berjamaah, dilanjutkan dengan ceramah dan diskusi keagamaan sampai menjelang waktu sholat isya'. Ketika waktu isya sudah tiba, maka salah seorang santri mengumandangkan azan sebagai pertanda akan dimulainya sholat isya. Sholat isya-pun dimulai dan dilaksanakan secara berjamaah. Setelah sholat isya' peserta mabit melakukan makan malam yang sudah disiapkan oleh panitia, kemudian mereka rehat sejenak. Satu jam kemudian, acara dilanjutkan dengan pembacaan barzanji atau selakaran dan membaca sholawat oleh grup Marawis. Pada jam tiga malam, peserta mabit bangun untuk melaksanakan sholat tahajjud dan amalan-amalan lainnya sampai menjelang sholat shubuh. Sehabis sholat shubuh, diadakan acara kultumyang diisi oleh seorang ustaz yang khusus diudang untuk mengisi acara tersebut, dan ustaz ini juga menginap bersama santri/wati. Sedangkan mabit yang berlangsung di masjid, peserta mabit adalah semua santri/wati yang berumur 10 tahun ke atas. Mereka tidur di masjid untuk melaksanakan dan mengikuti kegiatan yang sama. Sedangkan bagi santriwati yang berhalangan/datang bulan, mereka diberikan dispensasi untuk tidak mengikuti kegiatan mabit tersebut.

Setelah kurikulum direncanakan dengan matang dengan mempertimbangkan berbagai aspek sebagaimana dipaparkan di atas, maka langkah selanjutnya yang dilakukan dalam manajemen kurikulum adala mengorganisasikan kurikulum.

Pengorganisasian adalah keseluruhan proses untuk memilih orangorang serta mengalokasikan sarana dan prasarana untuk menunjang tugas orang-orang itu dalam organisasi. Dalam kesempatan tersebut narsumber mengutip pendapat Gibson dalam Syaiful, menyatakan pengorganisasian yaitu semua kegiatan manajerial yang dilakukan untuk mewujudkan kegiatan yang direncanakan menjadi suatu struktur tugas, wewenang dan menentukan siapa yang melaksanakan tugas tertentu untuk mencapai 
tugas-tugas yang diinginkan organisasi. Oleh karena itu dalam pengorganisasian bukan hanya mengindetifikasikan jabatan dan menentukan hubungan, namun yang paling penting adalah mempertimbangkan orang-orangnya dengan memperhatikan kebutuhannya agar berfungsi dengan baik.

Karena begitu pentingnya menempatkan seseorang sesuai dengan profesi dan keahliannya, maka Rasulullah SAW mengingatkan para pemimpin yang akan menempatkan seseorang secara profesional dengan sabdanya:

$$
\begin{aligned}
& \text { عن أبي هريرة رضي الله عنه قال: قال رسول الله صلى الله عليه وسلم: إذا ضيعت }
\end{aligned}
$$

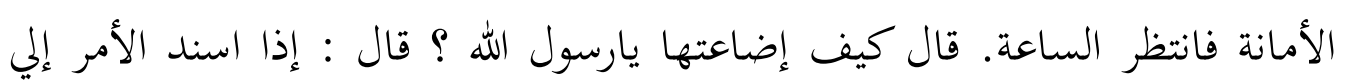

$$
\begin{aligned}
& \text { غير أهله فانتظر الساعة. رواه البخارى) }
\end{aligned}
$$

"Dari Abu Hurairah ra.ia berkata: Rasulullah saw bersabda: " apabila suatu amanah disia-siakan, maka tunggulah saat kehancurannya. (Abu Hurairah) bertanya: bagaimana menyia-nyiakan amanah itu, ya Rasulallah? Beliau menjawab: Apabila suatu perkaran diserahkan kepada orang yang bukan ahlinya, maka tunggulah saat kehancuran'(HR. Bukhari).

Mengutip hadis di atas, narasumber menegaskan kembali akan pentingnya masalah profesionalisme. Hadits di atas memberikan peringatan yang berperspektif manajerial karena amanah berarti menyerahkan suatu perkara kepada seseorang yang profesional. Dalam hadis tersebut Rasulullah mengulang kata-kata "فانتظر الساعة /maka tunggulah kehancuran", Nabi ingin mengingatkan ummatnya betapa pentingnya masalah profesionalisme. Implikasinya, hadits ini mendidik umatnya agar mengedepankan pertimbangan profesional dalam menentukan pegawai yang diamanati suatu pekerjaan atau tanggung jawab terlebih dalam perkara yang menyangkut persoalan orang banyak, misalnya jabatan bendahara sekolah dan sebagainya. 
Di samping menentukan pegawai secara proporsional dan profesional, dalam manajemen juga dituntut agar pimpinan sesegera mungkin memberikan upah, gaji, insentif atau honorarium kepada pegawai atau pekerja secepat mungkin (sebelum kering keringatnya), apalagi menunda sampai berbulan-bulan atau bahkan yang bersangkutan sudah lupa dengan honor yang akan diterimanya. Rasullah saw bersabda:

$$
\begin{aligned}
& \text { عن عبد الله بن عمر رضي الله عنهما قال: قال رسول الله صلى الله عليه وسلم: }
\end{aligned}
$$

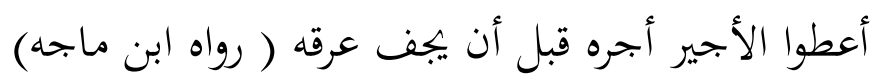

Dari Abdullah bin Umar ra. ia berkata: Rasulullah saw bersabda: berikanlah gaji/upah pegawai sebelum kering keringatnya" (HR. Ibnu Majah).

Hadits di atas berisi pendidikan agar seseorang memberikan penghargaan, dan dalam suatu lembaga pendidikan penghargaan ini sangat kondusif untuk mewujudkan kepuasan pegawai yang selanjutnya mampu membangkitkan tanggungjawab dan kedisiplinan. Menurut Jamal Madhi, "kedisiplinan merupakan gizi bagi para pekerja".

Di samping itu, bagi seorang pemimpin dalam rangka menciptakan kepercayaan bagi bawahannya hendaknya pemimpin memperhatikan dan mempraktikkan satunya kata dan perbuatan, dalam istilah sekarang terkenal dengan istilah " konsisten". Allah SWT berfirman dalam surah alShaaf ayat 2-3:

$$
\text { يأيها الذين أمنوا لم تقولون ما لا تفعلون. كبر مقتا عند الله أن تقولوا مالا تفعلون. }
$$

Wahai orang-orang yang beriman, kenapakah kamu mengatakan sesuatu yang tidak kamu kerjakan?. Amat besar kebencian di sisi Allah bahwa kamu mengatakan apa-apa yang tidak kamu kerjakan.

Ayat ini menyentuh persoalan kesesuaian antara perkataan dengan perbuatan, yang sekarang populer dengan istilah "konsisten". Sikap konsisten bagi pemimpin adalah suatu keharusan sebab dia adalah pemimpin yang menjadi panutan bagi bawahannya.

Berdasarkan pada pendapat di atas dapat dipahami bahwa keefektifan dalam pengorganisasian dapat menggambarkan ketepatan 
pembagian tugas, hak, tanggungjawab, hubungan kerja bagian-bagian organisasi, dan menentukan personal untuk melaksanakan tugasnya. Ini artinya bahwa pengorganisasian adalah proses menentukan hubungan yang esensial diantara orang-orang, tugas-tugas dan aktivitas-aktivitas dengan cara mengintegrasikan dan mengkoordinasikan semua sumber organisasi kearah pencapaian suatu tujuan secara efektif dan efisien.

Dalam kaitannya dengan pengorganisasian kurikulum, terdapat empat hal yang menandai pengorganisasiannya, yaitu: (1) pembagian tugas dan tanggung jawab, (2) pendelegasian wewenang, (3) banyaknya posisi yang tersedia, (4) pengelompokan bidang pekerjaan.

Tahap pelaksanaan ini merupakan tahap yang paling menentukan apakah di bawah kepemimpinan kepala sekolah dapat mewujudkan program sekolah atau tidak. Perencanaan dan pengorganisasian yang telah disusun akan dibuktikan keberhasilannya pada tahap pelaksanaan ini.

Pada pelaksanaan kurikulum tingkat sekolah, maka kepala sekolah yang bertanggung jawab untuk melaksanakan kurikulum di lingkungan sekolah yang dipimpinnya, sedangkan pelaksanaan kurikulum di tingkat kelas, maka yang berperan besar adalah guru.

Poin terpenting yang harus ada dalam strategi pelaksanaan kurikulum adalah: tingkat dan jenjang pendidikan, proses belajar mengajar yang meliputi metode dan tehnik pembelajaran, media dan sarana yang dibutuhkan, bimbingan dan penyuluhan, administrasi dan supervisi, serta evaluasi dan penilaian hasil belajar.

b. Manajemen Personalia

Perencanaan sumber daya manusia dimaksudkan untuk mengidentifikasi kebutuhan dan ketersediaan sumber daya manusia. Selain itu juga bertujuan untuk mengembangkan program-program dalam rangka meminimalisir penyimpangan-penyimpangan atas dasar kepentingan individu dan organisasi. Agar tujuan tersebut tercapai, maka perlu adanya job analysis, yakni proses pendeskripsian dan pencatatan tentang jabatanjabatan yang didasarkan pada uraian pekerjaan, yang meliputi komponenkomponennya seperti: tugas, tujuan, tanggungjawab, kondisi kerja dan karakteristiknya. 
Setelah perencanaan terhadap kebutuhan-kebutuhan dilaksanakan, selanjutnya lembaga pendidikan berusaha memenuhi kebutuhan tenaga sesuai dengan tipe pekerjaan, jumlah dan karakteristik personalia yang diperlukan.

Rekrutmen adalah usaha mencari dan mengadakan calon tenaga kerja yang potensial dengan jumlah dan mutu yang memadai, sehingga organisasi dapat memilih personalia yang benar-benar cocok dengan kebutuhan jabatan yang tersedia. Seleksi adalah proses pengumpulan data guna menilai dan memutuskan secara legal siapa yang dapat diangkat sebagai staf berdasarkan kepentingan individu dan organisasi untuk jangka pendek dan jangka panjang. Sedangkan penempatan merupakan upaya untuk menjamin bahwa kebutuhan jabatan dan karakteristik organisasi sangat cocok dengan keterampilan-keterampilan, pengetahuan, kemampuan preferensi, minat dan kepribadian yang dimiliki oleh calon pegawai atau anggota organisasi tersebut.

Langkah selanjutanya yang perlu dilakukan dalam manajemen personalia adalah penilaian prestasi kerja dan kompensasi yang diterima oleh masing-masing karyawan atau pegawai yang berprestasi. Dengan penilaian seperti ini sangat dimungkinkan terbangun etos kerja dan penciptaan produk yang baik sekaligus. Di samping itu, untuk meningkatkan kemampuan karyawan, pimpinan hendaknya memberikan kesempatan kepada karyawan untuk mengikuti pelatihan dan pengembangan. Hal ini dimaksudkan sebagai upaya untuk meningkatkan prestasi kerja para personalia saat ini dan di masa mendatang. Dengan kegiatan peningkatan pengetahuan dan keterampilan mereka dalam bekerjakegiatan pelatihan dan pengembangan tersebut perlu dilandasi prinsip-prinsip dasar pelaksanaan program pelatihan, yakni motivasi individu, pengakuan perbedaan individual kesempatan untuk melakukan kegiatan praktis, penguatan tujuan dan situasi belajar, serta semangat untuk pentransferan pengetahuan. 


\section{c. Manajemen Peserta Didik}

Manajemen peserta didik termasuk salah satu bagian dari manajemen pendidikan secara keseluruhan. Manajemen peserta didik menempati posisi yang sangat penting, karena sentral layanan pendidikan di sekolah adalah peserta didik. Semua kegiatan yang ada di setiap lembaga pendidikan diarahkan agar setiap peserta didik mendapatkan layanan pendidikan yang baik dan tercipta suasana belajar yang kondusif.

Tujuan manajemen peserta didik adalah mengatur kegiatankegiatan peserta didik agar kegiatan tersebut menunjang proses pembelajaran, sehingga dapat berjalan lancar, tertib dan teratur serta dapat memberikan kontribusi bagi pencapaian tujuan yang ditetapkan. Sedangkan fungsi manajemen peserta didik adalah sebagai wahana bagi peserta didik untuk mengembangkan diri seoptimal mungkin, baik dari segi individualitas, sosial, aspirasi kebutuhan ataupun potensi lainnya.

Ruang lingkup manajemen peserta didik antara lain meliputi: perencanaan dan penerimaan peserta didik, orientasi peserta didik baru, mengatur kehadiran atau ketidak hadiran peserta didik di sekolah, mengatur pengelompokan dan evaluasi peserta didik, mengatur tingkat peserta didik, mutasi dan drop out, mengatur kode etik dan peningkatan disiplin peserta didik, dan mengatur layanan peserta didik serta organisasi peserta didik.

d. Kegiatan Penutup

Dengan berakhirnya tanyajawab yang dilakukan antara narasumber dengan peserta pelatihan, maka seluruh rangkaian prosesi pelatihan dianggap sudah selesai, dan acara ditutup dengan sama-sama melafakan al-hamdallah dan dilanjutkan dengan penandatangan administrasi dan salam-salaman. 
Subki, Pelatihan Manajemen...

\section{KESIMPULAN}

Pelatihan tersebut diikuti oleh 15 orang peserta dengan rincian seorang kepala, empat orang wakil kepala, seorang bendahara, dan sepuluh orang tenaga pendidik atau guru yang memiliki latar belakang pendidikan serta jenjang pendidikan yang bervariasi. Di antara mereka ada yang masih duduk di bangku sekolah SLTA, bangku perguruan tinggi dengan jurusan yang berbeda antara satu dengan lainnya, dan dua orang sudah menyelesaikan pendidikan pada tingkat perguruan tinggi jenjang strata satu (S1). Sebagai narasumber pada kegiatan tersebut adalah M. Harja Efendi, M. Pd dan didampingi oleh tiga orang mahasiswa, yaitu Abdus Somad, Abdul Aziz dan Muhammad Nasir.

Kegiatan pelatihan dimaksud diselenggarakan melalui tiga tahapan, yaitu pendahuluan, diisi dengan berbagai macam kegiatan, antara lain pembagian ATK oleh pendamping, absensi peserta, dan pembukaan. Kegiatan inti terdiri dari tiga sesi, yaitu perkenalan, penyampaian materi terkait dengan manajemen Taman Pendidikan al-Qur'an, mulai dari konsep dasar manajemen, manajemen kurikulum, manajemen personalia dan peserta didik.

Manajemen kurikulum menempati urutan pertama dalam pelatihan tersebut karena bagi sebuah lembaga pendidikan termasuk lembaga pendidikan tempat pelatihan ini diselenggarakan yaitu Taman Pendidikan al-Qur'an Nurul Hidayah Getap Barat, kurikulum merupakan ruh dari lembaga pendidikan tertentu. Kurikulum berisikan materi dan jenis program yang akan dilaksanakan oleh sebuah lembaga pendidikan. Dalam kaitannya dengan manajemen kurikulum, pengelola lembaga pendidikan dituntut untuk merancang dan menjalankan program kegiatan yang memiliki keistimewaan dan sekaligus menjadi daya tarik bagi masyarakat sekitar untuk memasukkan putra-putrinya pada lembaga pendidikan yang bersangkutan.

Berdasarkan penuturan pengelola lembaga pendidikan Taman Pendidikan al-Qur'an Nurul Hidayah Getap Barat, diketahui bahwa lembaga pendidikan tersebut telah merancang dan melaksanakan beberapa program yang menjadi daya tarek masyarakat sekitar. Kegiatan-kegiatan atau program dimaksud antara lain: mawaris (pembacaan sholawat yang diikuti oleh seluruh santri/wati), Malam pembinaan iman dan takqwa (mabit) yang diikuti oleh santri/wati yang berumur 
10 tahun ke atas, dan khitobah atau pidato untuk mengembangkan bakat dan minat santri/wati.

Manajemen personalia dimaksudkan untuk memberikan informasi dan sekaligus pengetahuan kepada para peserta pelatihan khususnya pimpinan agar selektif dalam merekrut dan mendistribusikan job kepada masing-masing pengelola dan tenaga pendidik sesuai dengan jurusan dan kemampuannya. Demikian pula untuk meningkatkan kemampuan masing-masing tenaga atau pengelola, pihak pimpinan hendaknya memberikan kesempatan kepada tenaga pendidik atau pengelola lainnya mengikuti pelatihan dan pengembangan di setiap kesempatan, tentunya berkerjasama dengan berbagai pihak terkait.

Manajemen kesiswaan atau manajemen peserta didik menjadi hal yang paling penting dalam sebuah lembaga pendidikan. Karena peserta didik merupakan subyek dan sekaligus obyek bagi kelancara proses belajar mengajar. Terkait dengan manajemen peserta didik, lembaga pendidikan hendaknya memiliki dokumentasi dan pencatatan secara berkesinambungan, agar dapat diketahui kemampuan dan kapasistas kelas dan atau tenaga pendidik. Sehingga dengan demikian, maka proses belajar mengajar akan dapat berjalan sesuai dengan yang diharapkan.

\section{DAFTAR PUSTAKA}

http://elangjawa-hidup.blogspot.co.id/2014/05/manajemen-pengelolaan-tamanpendidikan.html.

Oemar Hamalik, Manajemen Pengembangan Kurikulum, Bandung: Remaja Rosydakarya, 2007

James A.F. Stoner, Management, New York: Prenticel /Hall International. Inc. 1982

George R Terry, Asas-asas Manajemen. Terj. Dr. Winardi. Cet. 8, Bandung: PT. Alumni, 2006

Sri Minarti, Manajemen Sekolah: Mengelola Lembaga Pendidikan Secara Mandiri, Jogjakarta: Ar- Ruzz Media, 2011

John R. Schermerhon, Jr. 1996, Management, 5" Edition. John Woley and Sone, Inc New York, Diterjemahkan oleh M. Purnama Putranta, 1997. 